Helene Marie Kjærgård Eide

Uni research Rokkansenteret

E-post: helene.eide@uni.no

Astrid Tolo

Institutt for pedagogikk

Universitetet i Bergen

\title{
Akademisk skriving og utvikling av skolelederkompetanse
}

\section{Sammendrag}

Akademisk skriving anses som vesentlig for studenters akademiske så vel som yrkesmessige kompetanseutvikling. Koblingen mellom akademisk skriving og yrkeskompetanse har imidlertid i liten grad vært empirisk undersøkt. Hensikten med studien er å belyse hvordan akademisk skriving bidrar inn i skolelederes kompetanseutvikling, og videre hvilke kvaliteter i tilbakemeldinger på tekster deltakerne opplever har betydning for kompetanseutvikling. Studien bygger vi på en kombinasjon av sosiokulturelle og kognitive perspektiver innenfor skriveforskning, og i den empiriske undersøkelsen følger vi fire skoleledere gjennom studieløpet. Datamaterialet i undersøkelsen er basert på disse fire skoleledernes tekster som skrives og bearbeides gjennom studiet, samt tre fokusgruppeintervju som undersøker betydningen av veiledning på tekstarbeidet for skolelederne.

Studien viser hvordan integrasjon av teoretisk og forskningsbasert kunnskap utvikles over tid i skoleledernes tekster, og hvordan skolelederne argumenterer for betydningen av veiledning og tilbakemelding i skriveprosessen. Gjennom skriving av ulike tekster i studiet skapes tydeligere koblinger mellom teori, forskning og refleksjoner rundt egen praksis og yrkesrolle. En tettere kobling mellom teori og praksis oppstår imidlertid ikke av seg selv, og resultatene peker mot at oppfølging over tid, mengde, presisjon og timing oppleves som viktige forutsetninger for at tilbakemeldinger fra veiledere og medstudenter skal bidra til at faglitteraturen kan informere skolelederpraksis på en hensiktsmessig måte.

Nøkkelord: yrkeskompetanse, lederkompetanse, skolelederutdanning, kompetanseutvikling, akademisk skriving

\begin{abstract}
Academic writing is perceived as pivotal in students' academic as well as professional competence development. However, the relation between academic writing and professional competence has not been empirically investigated. The purpose of this study is to examine how academic writing contributes into school leaders' competence development, and further what qualities in feedback on
\end{abstract}


texts the participants perceive as important for competence development. In the article we build on a combination of sociocultural and cognitive perspectives within writing research, and in the empirical study, we follow four school leaders through a study program of 18 months. The empirical material is based on texts and revisions of texts written by these four students. In addition, the material consists of data from three focus-group interviews with the same participants, investigating how the school leaders experience the integration of new theoretical and empirical knowledge in their thinking about the school leader role, and the significance of supervision in academic writing.

The study shows how the integration of theoretical and research based knowledge develops over time in the school leaders' texts, and how the school leaders argue for the importance of feedback and supervision in the writing process. Expressed in increased theoretical and empirical substantiation in the students' text, writing different texts helps the school leaders to relate theory and research to their own reflections on practice and professional role. Still, this integrated relation between theory and practice does not occur by itself. Here, our results point to supervision over time, the amount of feedback, precision, and timing as important prerequisites in order to make feedback from supervisors and fellow students contribute to making literature informative for school leader practices.

Keywords: professional competence, leader competence, school leader education, competence development, academic writing

\section{Innledning}

Skoleleders kompetanse er i søkelyset i dag på grunn av skoleleders nøkkelposisjon i et målstyrt utdanningssystem (Lillejord, 2011). I tillegg peker en rekke studier på skolelederen som avgjørende for god forvaltning og gode resultat (Day, Leithwood \& Sammons, 2008; Day et al., 2008; Leithwood \& Day, 2008; Robinson, 2010; Timperley, 2011). Hvordan utvikler skoleledere sin kompetanse og hva kan et skolelederstudium bidra med?

Kompetanse blir i denne artikkelen definert som det å kunne handle, altså at kompetente handlinger innebærer at handlingene en gjør blir styrt av ulike former for kunnskap, for eksempel erfaringskunnskap, empirisk kunnskap og teoretisk kunnskap, som er ervervet på mange ulike arenaer og til ulike tider (Tolo, 2011). Et slikt perspektiv er blant annet inspirert av "Teacher thinking”tradisjonen som utviklet seg på 1980-tallet, som en motreaksjon på at lærere og skoleledere var perifere i utdanningsforskningen. Den nye forskningstradisjonen var opptatt av at lærere og skoleledere ikke bare opptrer som hjul i utdanningsmaskineriet, men at de tenker og handler selvstendig, og at det de tenker har innflytelse på det de gjør, og det de gjør har innflytelse på det de tenker (Freeman, 
2002; Goodson, 1997). En forutsetning for å handle smart og effektivt som leder er å være i stand til å tenke godt om ledelse. I et lederstudium, på lik linje med andre studier, gir skriving mulighet til at studenten selv, medstudenter og lærere/veiledere får anledning til å inspisere kunnskap, tankerekker og forståelse som i neste omgang ligger til grunn for lederhandlinger. Mintzberg (2010) har tidligere pekt på ad-hocrazy som et gjennomgående trekk ved ledelse i alle typer organisasjoner. Ad-hocrazy kjennetegnes ved evne til å ta raske beslutninger ut fra situasjonsbestemte oppgaver. Samtidig krever god ledelse langsiktig tenkning, slik at ad hoc-beslutninger inngår i en større plan for hva en ønsker å oppnå. Leder handler altså både ut fra en langsiktig plan og ut fra "ryggmargsrefleksen” - og skriving i et studium gir anledning til å inspisere kunnskapen som ligger til grunn, og hvordan denne utvikler seg.

I den nasjonale satsningen på skolelederutdanning som har blitt finansiert av Utdanningsdirektoratet og blir tilbudt av høyere utdanningsinstitusjoner med ulike profiler, er akademisk skriving en sentral del av alle tilbydernes læringsprofiler. Evalueringen av de første tilbyderne i programmet (Lysø et al., 2012) viser at til tross for store ulikheter mellom de seks tilbyderne når det gjaldt struktur, antall og omfang av samlinger, eksamensform og litteraturomfang, vektla alle skriving av akademiske tekster som en vesentlig del av studentenes læring. Denne vektleggingen kan delvis begrunnes ut fra dokumentasjonskrav i høyere utdanning, hvor fagkunnskap kommer til uttrykk og dokumenteres gjennom skriftlige arbeider (Dysthe, Hertzberg \& Hoel, 2010). I evalueringen av rektorskolen forklares vektleggingen imidlertid ut fra nasjonale føringer hvor det argumenteres for at "programmene skal inneholde akademisk skriving med tanke på utvikling av analytisk tenkemåte og refleksjonsnivå” (Lysø et al., 2012, s. 43). Det vises blant annet til at akademisk skriving er vesentlig for studenters kobling mellom teori og praksis, og for utviklingen av argumentasjonsevne og evne til å ta ulike perspektiver (Lysø et al., 2012).

Denne antakelsen er i tråd med den sosiokulturelle tradisjonen innen skriveforskning hvor skriving knyttes til kognitiv utvikling, utvikling av kritisk tenkning og refleksjon (Bazerman, 1981, 1988, 2012; Flower, 1990; Bereiter \& Scardamalia, 1987; Kellogg, 2008; Çavdar \& Doe, 2012). Samtidig viser undersøkelser at skriveøvelser støtter studenters utvikling av faglig identitet og meningsdannelse (Caroll, 2002; Carter, Ferzli \& Wiebe, 2007; Bazerman et al., 2013). Akademisk skriving kan dermed anses som viktig for rektorskolestudentenes akademiske så vel som yrkesmessige kompetanseutvikling. At skriving fremmer rektorskoledeltakernes akademiske kompetanse, betyr imidlertid ikke at denne kompetansen er relevant for yrket som skoleleder. Til tross for at akademisk skriving hevdes å ha betydning for rektorskolestudentenes opplevelse av mestring og kompetanse (Lysø et al., 2012), har koblingen mellom akademisk skriving og yrkeskompetanse i liten grad vært empirisk undersøkt (Bazerman et al., 2013). I denne studien undersøker vi hvordan deltakerne på rektorskolen utvikler sin yrkeskompetanse gjennom å skrive akademiske tekster 
i løpet av studiet ved å stille spørsmålet: Hvilke forutsetninger må vcre til stede for at akademisk skriving skal bidra til utvikling av rektorskolestudenters lederkompetanse?

Artikkelen bygger på kunnskap om skriving som læringsstrategi og kunnskap om skoleledelse, og grunnlaget blir presentert i første del. Videre presenteres metodisk design og den empiriske studien av skriving i et skolelederstudium samt analytiske tilnærminger. Funnene viser hvordan studentene argumenterer for betydningen av veiledning og tilbakemelding i skriveprosessen, og viser hvordan progresjon skjer over tid, gitt at visse forutsetninger er til stede. Videre viser funnene hvordan studentene opplever at de utvikler en faglig tyngde som gir trygghet til arbeidet som skoleleder.

\section{Skriving som læringsstrategi}

I denne sammenheng bygger vi på en kombinasjon av sosiokulturelle og kognitive perspektiver innenfor skriveforskning, hvor skriving anses som en viktig strategi for læring. De sosiokulturelle perspektivene finner vi igjen blant annet i Bakthins (1981) og Rommetveits (1974) tenkning omkring mening og forståelse, hvor mening ikke er noe som overføres fra en person til en annen, men oppstår i en kommunikasjonssituasjon. De kognitive perspektivene finner vi hos Flower (1990), Bereiter og Scardamalia (1987) og Kellogg (2008) som ser på skriving som en evolusjonær prosess i den enkeltes læring. Skriving er, sett ut fra begge perspektiver, et verktøy den lærende kan benytte når en tilegner seg, gir mening til og anvender faglig kunnskap (Dysthe, Hertzberg \& Hoel, 2010). I vår sammenheng er skriving som læringsstrategi knyttet til det vi kaller akademiske tekster, hvor innholdet i tekstene skal bygge på egne erfaringer, teori og forskning, samt følge spesifikke krav til struktur og referanseteknikk. Studentenes fagtekster er således avhengige av andre tekster og står i et dialogisk forhold til dem (Dysthe, 1999).

I læringsprosessen har skriving både en analytisk og en sammenbindende funksjon (Bazerman, 1988, 2012; Kellogg, 2008; Çavdar \& Doe, 2012). Det vil si, det blir satt i gang ulike læringsprosesser som forsterker hverandre gjennom skrivingens multirepresentative arbeidsmåte (Dale, 1983; Dysthe, Hertzberg \& Hoel, 2010). Når en skriver faglige tekster, innebærer disse prosessene at en tilegner seg ny kunnskap gjennom å lese andres tekster, for så å bearbeide det en har lest ved å skrive om det. Når vi skriver, ordnes og omformes tanker, og videre kan en se sammenhenger eller mangel på sammenhenger mellom dem. I rektorutdanningen er sammenhengen mellom skrivingens analytiske og sammenbindende funksjon således vesentlig i studentenes eget skrivearbeid, men også i tilegnelsen av teori.

Når en skriver fagtekster, er det særlig to forhold som er av betydning. Det ene er evne til å skille ut relevant kunnskap fra annen kunnskap i tekster 
(Flower, 1990), og det andre er evne til reformulering, eller omforming av kunnskap (Bereiter \& Scardamalia, 1987). Gode akademiske skrivere kjennetegnes av at de greier å skille ut hva som er relevant, og at tekstene de skriver karakteriseres av en slags dialog hvor de forklarer mer enn å gjengi det de har lest (Flower, 1990). Det er dette siste kjennetegnet som kalles reformulering. Reformulering innebærer således at den som skriver ikke bare gjenforteller innholdet i det en har lest, men omformer det og «gjør det til sitt eget» ved å relatere det til en aktuell sammenheng (Dysthe, Hertzberg \& Hoel, 2010).

I arbeidet med reformulering skapes det koblinger mellom den enkelte student, de erfaringene denne har med seg, og det fagstoffet en skal tilegne seg. Ulike fag har imidlertid ulike tradisjoner for hvordan ervervet kunnskap kommer til uttrykk (Dysthe, Hertzberg \& Hoel, 2010). Forskning viser da at skriving ikke bare bidrar i studenters læring, men også i utvikling av faglig identitet og meningsdannelse (Caroll, 2002; Carter, Ferzli \& Wiebe, 2007; Bazerman et al., 2013). I denne sammenheng er det et poeng at de aller fleste deltakerne i skolelederutdanningen allerede er en del av en fagtradisjon, ved at de har erfaring som lærer og leder, og de er i lederstilling mens de tar studiet. Kompetanseutvikling, faglig identitet og meningsdannelse bygges på solide erfaringer, og skriving i studiet kan her hjelpe dem i å rydde, nyansere, informere og gi retning til arbeidet de allerede står i.

I vurderingslitteraturen blir tilbakemelding, eller feedback, beskrevet som noe av det som gir læringen progresjon og retning mot et mål. Formativ vurdering foregår ved at en henter frem dokumentasjon på studentens progresjon (som i denne sammenhengen er en oppgave); dette blir tolket og brukt av veilederen, medstudenter og studenten selv som grunnlag for beslutninger om hva som skal være neste steg i læringsprosessen (Black \& William, 2009, s. 9). I et kognitivt perspektiv ser en på de ulike trinnene i læringsprosessen som en del av den naturlige utviklingen innen et område, og læreren veileder for eksempel ut fra det en vet om progresjon i skriving av akademiske tekster. Sett fra et sosiokulturelt perspektiv, som er relevant i denne sammenheng, legger en vekt på forhandlingene og kommunikasjonen om hva som gir mening - når får studenten noe ut av arbeidet med teksten som støtter opp om kompetanseutviklingen som skoleleder? Dialogen mellom veileder, medstudenter og student kan være med på å skape mening i fellesskap. Både studiedesignet (hvilke oppgaver som blir gitt, krav om bearbeiding av oppgaver etter en har fătt tilbakemelding, og timing med hensyn til når tilbakemeldingen blir gitt av veileder eller når arbeidet skal bearbeides av student), og tilbakemeldingens form og innhold viser seg å avgjøre om en tilbakemelding faktisk blir brukt av studenten for videre læring (Dysthe, 2011; Gamlem \& Smith, 2013). 


\section{Skolelederkompetanse}

Innledningsvis forklarte vi kompetanse som det å kunne handle, og at en forutsetning for å handle smart og effektivt som leder er å være i stand til å tenke godt om ledelse. Hva det vil si å tenke godt om ledelse, diskuteres og defineres fra ulike hold. Her tar vi utgangspunkt i Utdanningsdirektoratets kompetansemodell som ble introdusert i 2008, da den nasjonale skolelederutdanningen ble etablert. I Utdanningsdirektoratets kompetansemodell består skolelederkompetanse av fire kompetanseområder: 1 . Elevenes læringsresultater og læringsmiljø. 2. Styring og administrasjon. 3. Samarbeid og organisasjonsbygging, og veiledning av lærere. 4. Utvikling og endring. I tillegg til de fire områdene bygger modellen opp rundt en kjerneforståelse av selve lederrollen, hvor den enkelte leder opplever seg trygg i rollen og utviser mot og kraft til å lede (Andreassen, Irgens \& Skaalvik, 2010). Lederkompetanse viser i denne modellen altså til en tverrfaglig, sammensatt kompetanse (Møller, 2011). Skolelederkompetanse må følgelig forstås som et bredt kompetansebegrep, hvor helhetstenkning er essensielt både for skolelederes forståelse av egen rolle og i utøvelsen av ledelse. Et slikt sammensatt kompetansebegrep stiller store og omfattende krav både til skolelederes kunnskap og til deres ferdigheter (Møller \& Ottesen, 2011).

I et komplekst kompetansebegrep er de fire kompetanseområdene avhengige av hverandre (Andreassen et al., 2010). Det innebærer at det som gjøres eller ikke gjøres i ett område, får betydning også for de andre områdene. For eksempel viser forskningen at skoleledere jobber med miljø og læringsresultat indirekte, gjennom å påvirke lærernes motivasjon, engasjement og gjennom å skape et godt arbeidsklima for lærerne (Leithwood, Harris \& Hopkins, 2008, s. 32). Forskningen tilsier altså at skoleleders ansvar for elevenes læringsmiljø og læringsresultater vanskelig kan skilles fra lederens arbeid med personalledelse og veiledning av lærere. Denne sammenhengen understrekes ytterligere av Robinson (2010) som argumenterer for at skolelederkompetanse kommer til uttrykk i lederes evne til: a) å formulere og etablere mål og forventninger i egen organisasjon, b) strategisk ressursutnyttelse, c) planlegging, monitorering og deltakelse i undervisnings- og læreplanrelaterte aktiviteter, d) deltakelse i og fremheving av læreres læring og utvikling, og e) å sikre et støttende og utviklingsorientert arbeidsmiljø for både elever og lærere. Å utvikle skolelederkompetanse må følgelig handle om at en utvikler flere kapasiteter og kunnskapsområder samtidig.

I norsk sammenheng har man utformet et nasjonalt utdanningsprogram for å sikre kompetanseutvikling for skoleledere. Utdanningen har blitt evaluert (Lysø et al., 2012), og skriving har i den sammenheng blitt tematisert. Vi har imidlertid lite dybdekunnskap om hvordan skriving bidrar til skolelederes kompetanseutvikling. Det er også lite kunnskap om hvordan en metodisk kan gå til verks for å belyse skriving i denne typen yrkesutdanning. Vår artikkel er ment som et bidrag i denne sammenheng. 


\section{Metodisk design for studien}

Denne undersøkelsen er en kvalitativ studie, gjennomført av to av de ansvarlige ved ett av de syv tilbudene om videreutdanning for skoleledere som ligger inne i den nasjonale "rektorskolesatsningen". Intensjonen med studien er at den skal bidra til å utvikle mer kunnskap om hvordan akademisk skriving bidrar inn i skolelederes kompetanseutvikling, samt å belyse kvalitet i undervisning og veiledning i studieprogrammet.

I det konkrete tilbudet studien er gjennomført i, blir det arrangert færre samlinger og samlingene har kortere varighet enn i de andre nasjonale tilbudene (Lysø et al., 2012). Skriving av akademiske tekster vektlegges som en vesentlig del av undervisningen. Studentene blir bedt om å skrive 4 læringsnotat/ refleksjonsnotat (1-2 sider), en utviklingstekst der studentene skal skrive om et utviklingsprosjekt på egen skole (4000 ord) og en fordypningstekst der de svarer på en definert oppgave (3000 ord). I alle tekstene blir det forventet at studentene belyser egne erfaringer som skoleledere med faglitteratur på området, og det stilles krav til struktur og referanseteknikk. Refleksjonsnotatene er levert i etterkant av 2.-4. studiesamling og er kortere tekster hvor deltakerne ut fra samlingenes tema er bedt om å vise på hvilken måte hele eller deler av det aktuelle fagstoffet kan medvirke til økt forståelse for egen rolle og praksis. I utviklingsteksten har studentene fått $\mathrm{i}$ oppgave å utforme en problemstilling knyttet til ett av utviklingsprosjektene de arbeider med i egen skole. Et krav til problemstillingen er her at denne skal ha et klart ledelsesperspektiv hvor deltakerne blir utfordret til å diskutere og belyse ledelsesutfordringer i prosjektgjennomføring i egen skole. Denne teksten er av et større omfang, og deltakerne arbeider med teksten gjennom hele studietiden hvor de leverer inn og mottar muntlig og skriftlig tilbakemelding fra veiledere og medstudenter i sammenheng med studiesamlingene. Den siste tekstsjangeren er en fordypningstekst hvor deltakerne er bedt om å diskutere en definert problemstilling. Her har deltakerne hatt mulighet til å velge blant fem ulike alternative problemstillinger. Som i tilfellet med utviklingsteksten er også fordypningsteksten av et større omfang og gjenstand for tilbakemeldinger fra medstudenter og veiledere gjennomgående gjennom studiet. Utviklingstekst og fordypningstekst blir levert inn som eksamenstekster til slutt i studiet. Tilbudet skiller seg på denne måten fra de andre seks tilbyderne i struktur og eksamensform.

For å få innsikt i tekstarbeid og opplevelse av relevans for yrket fant vi det hensiktsmessig å studere studenttekster og hvordan disse utviklet seg gjennom studiet som strekker seg over $1 \frac{1}{2} \mathrm{a}$ å, og å intervjue studentene om det å skrive tekstene. Alle studentene på kullet fikk spørsmål om å være med; fire meldte seg, en mann og tre kvinner. To av deltakerne i studien er rektorer, mens to er avdelingsledere. Rollefordelingen mellom de fire avspeiler således fordelingen mellom rektorer og avdelingsledere i studentkullet de er en del av. I tabellen under gis en kort presentasjon av den enkelte deltaker: 
Tabell 1: Presentasjon av deltakerne i studien

\begin{tabular}{|c|c|c|c|}
\hline $\begin{array}{l}\text { Egil er rektor på en } \\
\text { mellomstor ungdoms- } \\
\text { skole. Han har vært } \\
\text { rektor ved skolen i mer } \\
\text { enn fem år og har fra } \\
\text { tidligere lang erfaring } \\
\text { som avdelingsleder (in- } \\
\text { spektør). Egil har også } \\
\text { erfaring fra arbeid } \\
\text { som leder utenfor } \\
\text { skolen. }\end{array}$ & $\begin{array}{l}\text { Silje arbeider ved en } \\
\text { barneskole. Hun har } \\
\text { nylig startet i avdel- } \\
\text { ingslederstilling ved en } \\
\text { ny skole. Dette er } \\
\text { hennes første skole- } \\
\text { lederstilling. Tidligere } \\
\text { var hun lærer ved en } \\
\text { annen skole i kom- } \\
\text { munen. }\end{array}$ & $\begin{array}{l}\text { Hanne arbeider ved } \\
\text { en barneskole. Hun } \\
\text { har nylig startet i } \\
\text { avdelingslederstilling } \\
\text { ved skolen etter flere } \\
\text { å som lærer ved } \\
\text { denne skolen. Dette } \\
\text { er hennes første } \\
\text { skolelederstilling. }\end{array}$ & $\begin{array}{l}\text { liten, kombinert skole } \\
\text { (1.-10. trinn). Hun har } \\
\text { flere års erfaring som } \\
\text { skoleleder og er nå } \\
\text { inne i sitt tredje år som } \\
\text { rektor ved skolen. Tid- } \\
\text { ligere har hun hatt av- } \\
\text { delingslederstilling og } \\
\text { lærerstilling ved den } \\
\text { samme skolen. }\end{array}$ \\
\hline
\end{tabular}

Datamaterialet består av disse fire deltakernes tekster samt tre fokusgruppeintervju. I fokusgruppeintervjuene undersøkes skoleledernes opplevelse av integrering av ny teoretisk/empirisk kunnskap i egen tenkning rundt yrkesrollen, og betydningen av veiledning på tekstarbeidet. Tekstanalysene og fokusgruppeintervjuene er basert på det samme utvalget. Datagrunnlaget er samlet inn i tidsrommet november 2014 til november 2015. Studenttekstene er lastet ned fra studiets læringsportal hvor studentene leverer tekster i forbindelse med studiesamlingene. På læringsportalen har også tilbakemeldingene på tekstene fra veiledere vært tilgjengelige. Av praktiske årsaker har vi valgt å gjennomføre fokusgruppeintervjuene i sammenheng med studiesamlingene, hvor første intervju ble gjennomført i vårsemesteret 2015, mens de to siste intervjuene ble gjennomført høsten 2015. De tre intervjuene har hatt ulik form og varighet, hvor det første intervjuet kan karakteriseres som en semi-strukturert gruppesamtale (Kvale \& Brinkmann, 2009), mens de to siste samtalene har hatt et klarere definert siktemål uttrykt gjennom konkrete oppgaver deltakerne skulle løse (Halkier, 2010).

Studien er meldt til Norsk samfunnsvitenskapelig datatjeneste (NSD) og følger grunnleggende forskningsetiske forutsetninger som informert samtykke og frivillig deltakelse for den enkelte (Hatch, 2002; Silverman, 2011). Både i tekstmaterialet og i transkripsjonene av intervjuene er deltakerne anonymisert. I presentasjonen er deltakerne gitt dekknavn: Egil, Silje, Hanne og Anita. Selv om utvalget er lite, er materialet omfattende (om lag 208 sider med tekst og intervjutranskripsjoner; tilbakemeldingene på studenttekstene er ikke iberegnet her).

Forskerne er selv involvert i studieopplegget, og det er derfor fare for enn viss bias. Fordelen med å kjenne opplegget fra innsiden er at en kan stille detaljerte spørsmål med bakgrunn i erfaring med hva som for eksempel synes å være utfordrende for studentene, og få svar på det en har lurt på. Samtidig er det en fare for at en ubevisst taler for og forsvarer sin egen praksis både i intervjuene og i tolkning av data. En må også ha i tankene at svarene informantene gir i intervjuene, kan være preget av at de uttaler seg til to av de ansvarlige for studiet. Dette er kjente problem i kvalitativ forskning på egen praksis og løses bare gjennom høy grad av transparens, at vi er tydelige på egen rolle, viser teoretisk perspektiv, hvilken tidligere forskning vi bygger på, og hvordan data er 
produsert og analysert (Malterud, 2003). Vi mener at undersøkelsen har gyldighet i form av det Kvale og Brinkmann (2009) kaller kommunikativ validitet, da resultatene av vår analyse er diskutert med andre forskere og sammenstilt med andre forskningsfunn. Videre kan vår undersøkelse brukes som utgangspunkt til refleksjon rundt akademisk skriving i en videreutdanningskontekst samt grunnlag for videre forskning, refleksjon og diskusjon blant skolelederutdannere, noe som vil styrke den kommunikative validiteten i arbeidet.

\section{Analytiske tilnærminger til studenttekster og intervju}

Det empiriske materialet i undersøkelsen er omfattende og består som nevnt av både studenttekster og fokusgruppeintervju. For å gjøre beskrivelsen av de analytiske tilnærmingene til materialet mest mulig transparent har vi derfor valgt å dele presentasjonen inn i to deler: 1) analyse av studenttekster, og 2) analyse av intervju.

1. Vi har analysert både kortere og lengre tekster. De ulike tekstene har blitt kategorisert og analysert både ut fra hva deltakerne er bedt om å gjøre i oppgavene (sjanger), og ut fra ulike kategorier som går på tvers av oppgavetyper. Kategoriene er utviklet etter inspirasjon fra Kelloggs (2008) modell for skriveferdigheter og Bazerman med fleres (2013) analyse av lærerstudenters kognisjonsutvikling gjennom skriveoppgaver i et lærerutdanningsprogram. Hensikten med kategoriene er at de skal kunne synliggjøre a) deltakernes refleksjoner over tematisk innhold i studiet, b) deltakernes refleksjoner rundt egen lederrolle, c) deltakernes refleksjoner rundt egen læring, og d) utvikling og endring i deltakernes argumentasjonsuttrykk og integrasjon av teoretisk kunnskap i egen tenkning (se appendiks 1 for nærmere kategoriforklaring og eksemplifisering). Slik har analysen vært orientert mot både innhold (kategori a-c) og form (kategori d) i tekstene. Tekstanalysen har videre hatt form som en trinnvis prosess hvor deltakernes tekster i det første trinnet ble kategorisert i tråd med de tre innholdskategoriene. I det neste analysetrinnet har oppmerksomheten vært rettet mot integrasjon av teoretisk kunnskap i innholdskategoriene, og hver av de tre innholdskategoriene har blitt ytterligere delt inn i to underkategorier, en bestående av utsagn hvor påstander skrives frem uten at dette kobles til litteratur, teori eller forskning, og en med utsagn hvor deltakerne kobler sammen egne refleksjoner/erfaringer med litteratur eller forskning. For å få oversikt over hver av tekstene har vi i dette andre trinnet utformet matriser til hver enkelt tekst deltakerne har levert (se appendiks 2 for illustrasjon). I det tredje trinnet i analysen har vi konsentrert oss om tekstenes form, gjennom en egen kategori (d) som betegner kvaliteter ved teksten som angår litteraturanvendelse. I dette trinnet har vi opprettet et skille mellom rene sitater fra forelesninger eller litteratur og tekstutsagn som preges av reformulering. Som en avslutning ble formkategorien integrert sammen med innholdsmatrisene til hver av tekstene. På denne måten har vi foretatt en analyse som illustrerer hvilke tematiske områder deltakerne bearbeider og knytter ny teoretisk og forskningsmessig kunnskap til, og videre har vi 
ved å sammenstille matrisene kunnet følge deltakernes utvikling i bearbeidelsen av ny kunnskap over tid.

2. I analysen av fokusgruppeintervjuene har hensikten vært å få frem deltakernes opplevelse av læring og kompetanseutvikling i forbindelse med skrivearbeidet. Fokusgruppeintervju er valgt fordi denne formen for intervju er spesielt egnet til å produsere data som belyser normer for gruppers praksiser og fortolkninger (Halkier, 2010). Gjennom samhandling mellom deltakerne kan en fremskaffe data som illustrerer hva en gruppe kan bli enige om eller uenige om. Fokusgrupper illustrerer således gruppedeltakernes forhandlinger rundt normative aspekter ved ulike praksiser (Halkier, 2010). I denne studien har intensjonen vært å innhente data som kan gi innsikt i rektorenes læringsopplevelse over tid, samt å utvikle kunnskap om eventuelle endringer i skolelederes rolleoppfatning og opplevelse av kompetanse. Vi har derfor valgt å gjennomføre tre fokusgrupper med ulik form, for de samme deltakerne.

Analysen bygger på transkripsjoner fra 3 fokusgruppeintervjuer, gjennomført i tidsrommet april 2015-november 2015. Varigheten av intervjuene varierer fra 45 til 90 minutter. Analysen av fokusgruppeintervjuene har vært rettet mot å avdekke deltakernes perspektiver på skriving som læringsstrategi og skriving som redskap for utvikling av lederkompetanse. For å kunne belyse problemstillingen har vi derfor delt lesningen av transkripsjonene inn i to steg, hvor hver lesning har hatt et overordnet spørsmål. I det første steget har vi stilt spørsmålet: Hva bidrar skriving til? I denne lesningen har hensikten vært å avdekke hva deltakerne opplever at skriving bidrar til. Ut fra materialet har vi etablert to ulike kategorier, hvor den ene kategorien omhandler hva skriving bidrar til i deltakernes læring i studiet, og den andre kategorien omhandler hva deltakerne beskriver at skriving bidrar til i lederrollen. I det neste steget har vi stilt spørsmålet: Hva må til for at skriving skal bidra? I denne lesningen har hensikten vært å avdekke hvilke forutsetninger deltakerne beskriver at må være til stede for at skriving skal bidra til læring og kompetanseutvikling. I intervjuene har det med utgangspunkt i deltakernes utsagn vært rettet særlig oppmerksomhet på tilbakemeldinger på tekstene de leverer, og hvordan de arbeider med tilbakemeldinger fra veiledere og medstudenter. I det følgende vil vi derfor konsentrere oss om hvordan deltakerne i studien opplever at tilbakemeldinger bidrar som forutsetning for at akademisk skriving skal bidra til utvikling av rektorskolestudenters lederkompetanse.

Vi vil videre presentere de mest sentrale funnene i analysen.

\section{Veiledning og tilbakemeldinger har betydning for kunnskapsutvikling i studenttekster}

I alle fokusgruppeintervjuene gir deltakerne uttrykk for at skriving er meningsfylt og har betydning for deres egen opplevelse av læring og kompetanse- 
utvikling i studiet. I tillegg trekker deltakerne frem det de mener er nøkkelen til god veiledning. Skriving må jobbes med for at en skal få det til, studentene trenger tilbakemelding, og det skjer en utvikling over tid. Vi skal i det følgende illustrere dette gjennom sitater fra studenttekster som fremstår som typiske i det store materialet.

Når det blir stilt krav om akademisk skriving, blir studentene nødt til å lese. Egil sier det slik: "Skrivingen har vært god fordi du blir presset til å lese litteraturen, både i refleksjonsnotatene og selvsagt i de to oppgavene” (3. fokusgruppe). Når Egil sier at han opplever seg presset til å lese litteraturen, skyldes det at oppgavene han møter i studiet, legger opp til at koblingene mellom teori og Egils refleksjoner over egen praksis skal gjøres eksplisitte i tekstene han skriver.

I intervjuene gir alle deltakerne uttrykk for at de opplever å ha fått en sterkere teoretisk forankring for egen praksis. Analysen av deltakernes tekster viser imidlertid at koblingen mellom egne erfaringer, forskning og teori ikke kommer av seg selv, men må arbeides med systematisk og over tid. Dette er vanskelig og handler om hvordan erfaringer og spesifikk kunnskap fra ulike områder integreres i hverandre og fører til økt kompetanse (Bazerman et al., 2013). I tekstutdraget under, hentet fra en av deltakernes første refleksjonsnotat, kommer denne utfordringen til uttrykk, og den er typisk i den forstand at alle studentene skriver på denne måten i begynnelsen. Vi ser hvordan deltakerne i starten av studiet skriver frem påstander og refleksjoner rundt egen praksis:

Også skuleeigaren vår har for lite kjennskap til korleis det vert jobba med vurdering. Dei vert “eit kontrollorgan” og ikkje ein støttespelar til å utvikla ein god og lærande organisasjon. (Læringsnotat 1).

Utdraget over er typisk for deltakernes innledende tekster og viser hvordan deltakeren reflekterer over samhandling mellom skoleleder og skoleeier i arbeidet med vurdering i egen skole. Her brukes flere begreper som potensielt åpner for at deltakeren kan se på arbeidet med vurdering i et analytisk perspektiv, for eksempel begrepene støttespiller, kontrollorgan og lærende organisasjon. I teksten knyttes imidlertid ikke disse begrepene til et meningsinnhold eller tydelige perspektiver, men fremstår som deltakerens egendefinerte posisjoner mellom skoleeier og skoleleder. Deltakerens refleksjoner stopper da opp ved egen erfaringsbasert kunnskap og utvikles ikke videre (Bazerman et al., 2013). Det blir da en veilederoppgave å sørge for at deltakerne i sterkere grad tolker sine erfaringer i lys av overordnede og analytiske perspektiver. Slik sett ser vår analyse ut til å bekrefte Lysø med fleres (2012) argument om at det er grunn til å ilegge veilederrollen en sentral funksjon når det gjelder deltakernes integrasjon mellom erfaringsbasert og mer spesifikk teoriforankret kunnskap.

Analysen av tekstene har videre avdekket at deltakerne har utfordringer med å bearbeide og omforme teori til analytiske begreper som kan tas i bruk når de prøver å forstå sin egen praksis. Her kommer det frem at arbeidet med å om- 
forme teori har et prosessuelt preg som innledes med at teoretiske perspektiver først integreres i tekstene i form av sitater. Dette kan forstås i retning av at deltakerne først har fanget opp tilbakemeldinger om at det kreves faglig underbygning for argumentasjonen, ikke at denne underbygningen skal bearbeides. I et utdrag fra en av deltakernes andre versjon av utviklingsteksten ser vi et typisk eksempel på dette, hvor deltakeren kobler på et sitat mot slutten, uten at sitatet bearbeides videre og brukes aktivt for å forklare den konkrete situasjonen som beskrives:

Dette kom tydeleg fram då personalgruppa saman gikk gjennom resultatet på dei nasjonale prøvane hausten 2013. I etterkant av dette møtet kom nokre av lærarane til oss i leiinga og antyda at dette opplevde dei som ubehageleg og som eit fokus på den enkelte lærar som hadde ansvar for faget i forhold til dei nasjonale prøvane. Det vart understreka at det var ekstra ubehageleg for den læraren som då oppnådde eit ikkje forventa resultat med sine elevar. Susan Rosenholtz har forska på samarbeidsbaserte kulturar. Ho set søkelyset på to ulike typer skolekulturar i sitt utval; fastlåst og i bevegelse. I skoler i bevegelse tenker man at undervisningsforbedring er en kollektiv snarere enn individuell innsats. Man antar at analyse, vurdering og eksperimentelle metoder - benyttet sammen med kolleger - er forhold som stadig vil forbedre lærere (Hargraves og Fullan, 2014, s. 131). (Utviklingstekst 2)

Utdraget over viser hvordan koblingen mellom teori og praksis innarbeides i teksten ved at Rosenholtz' fremstilling av ulike samhandlingskulturer i skolen kobles på i form av et sitat. I sitatform fremstår imidlertid de analytiske begrepene mer som en reproduksjon enn som reformulering (Dysthe, Hertzberg \& Hoel, 2010; Bazerman et al., 2013), hvor de analytiske perspektivene er noe skolelederen kan ta i bruk når hun prøver å forstå sin egen praksis. Eksempelet viser hvordan arbeidet med teori i seg selv krever tid og omarbeiding for at denne skal ha form som kunnskap skriveren "skaper selv" og kan ta aktivt i bruk i egen yrkesutøvelse (Kellogg, 2008). Vår analyse av deltakernes tekster viser også at denne omarbeidelsen som regel ikke skjer dersom den ikke blir adressert fra enten veiledere eller medstudenter. Dialog mellom deltaker og veiledere, skriftlig eller muntlig, (Dysthe, Hertzberg \& Hoel, 2010) ser med andre ord ut til å ha stor betydning for deltakernes utvikling av kunnskap, mening og forståelse.

Veiledning og tilbakemeldinger på tekstene som utfordrer deltakerne til videre teoribearbeidelse, fremstår i vår analyse som avgjørende for å bringe deltakerne videre i prosessen med omforming av teoretisk og analytisk kunnskap, begreper og perspektiver. Når vi ser på utviklingen i deltakernes tekster gjennom studiet, finner vi at det først er i studieløpets siste halvår at tekstene preges av slik omarbeidelse. Dette kan ha sammenheng med at en da nærmer seg eksamen, og studenten må få ting på plass. I utdraget under, hentet fra det tredje læringsnotatet, vises slik omarbeidelse av kunnskap gjennom en av deltakernes tanker rundt målsettinger i studiet: 
Eit mål med rektorskulen er å gjere oss medvitne om det og «tvinge» oss til å prioritere utviklingsarbeid. Ein kan få fleire vinstar ut av det: betre samhald i kollegiet, meir uttalte mål og ein levande visjon for alt arbeid ved skulen. Robinson (2006) kallar dette motsetnaden mellom generell og edukativ leiing. For å få betre elevresultat treng ein meir edukativ læring og mindre av den generelle. Dette er eit paradigmeskifte som ein ikkje har tatt konsekvensane av i kommunane. (Læringsnotat 3)

Som utdraget over viser, er det først når deltakerne kobler på egne perspektiver på teori og forskning det refereres til, at en får inntrykk av deltakernes kunnskapstilegnelse (Kellogg 2008, Bazerman et al., 2013). Vår analyse av tekstene viser at prosessen med omforming går raskere der hvor deltakerne har mulighet til å revidere tekster fremfor å skrive nye for å ta veiledning og tilbakemeldinger i bruk. Muligheten for revisjon innebærer imidlertid ikke alltid at tilbakemeldinger bidrar til læring eller utvikling av tekstene.

\section{Tilbakemeldinger som forutsetning for kompetanseutvikling: mengde, presisjon og timing}

I intervjuene peker deltakerne på tre ulike aspekter som har betydning for hvorvidt tilbakemeldinger og veiledning oppleves som konstruktivt og læringsfremmende: Mengden av tilbakemelding må være avpasset, tilbakemeldingen må være presis og konkret, og den må komme i rett tid. Disse funnene er i tråd med tidligere forskning (Dysthe, 2011; Gamlem \& Smith, 2013), men vi vil illustrere hvordan dette kom til uttrykk i skolelederutdanningen.

Det første aspektet som deltakerne peker på i intervjuene, er mengden tilbakemelding som gis. Deltakerne knytter dette til at for mange tilbakemeldinger oppleves som overveldende. I det andre fokusgruppeintervjuet beskriver Silje at: «Når en får for mye tilbakemelding fra veileder, tar det piffen fra en. Jeg vet ikke hvor jeg skal starte. Det tar liksom helt overhånd, alt jeg skal arbeide med.» Silje beskriver at det er utfordrende å vurdere hva hun skal prioritere å gripe fatt i og arbeide videre med, dersom veileder gir mange tilbakemeldinger eller innspill som innebærer omfattende omarbeidelse av tekstene. Store mengder tilbakemelding virker da demotiverende og utfordrer opplevelsen av mestring fordi det blir vanskelig å sortere og prioritere i den videre bearbeidelsen av teksten.

Alle deltakerne peker videre på presisjon som vesentlig for at tilbakemeldinger skal oppleves som læringsfremmende. Egil forklarer presise tilbakemeldinger slik:

En god tilbakemelding må være presis. En presis tilbakemelding kan være at du får spørsmål om hvorfor du har hentet frem en teori om du ikke bruker den videre i teksten, eller spørsmål om hvor du har noe fra. Har du teorigrunnlag for det du hevder her? Det er sånne ting som får deg til å tenke. (1. fokusgruppeintervju) 
Presise tilbakemeldinger handler da, ifølge Egil, om at de er knyttet til konkrete aspekter ved teksten hans og utfordrer måten han arbeider med teori på. Tilbakemeldingene trenger ikke å fortelle noe konkret om hva han bør gjøre, men utfordrer refleksjonen hans ved å være formulert som spørsmål. Dette åpne aspektet peker også Hanne på som viktig når hun forklarer at hun forstår innspill fra veileder som "fremovermeldinger": "Jeg ser på tilbakemeldingene som gode tips videre, eller en tanke eller et spørsmål jeg kan reflektere videre rundt” (2. fokusgruppe). Hanne ser på innspill fra veileder som tips og inspirasjon til videre refleksjon. Hun oppfatter dermed ikke tilbakemeldingene som korrektiver slik Silje beskriver dette i avsnittet over.

Det siste aspektet deltakerne beskriver som avgjørende for hvorvidt de opplever tilbakemeldingene som læringsfremmende, er timing. For noen av deltakerne opplevdes dette som et særlig kritisk aspekt, ettersom de opplevde at veiledningssituasjonen ikke fungerte tilfredsstillende. I det andre fokusgruppeintervjuet beskriver Egil at han i denne situasjonen opplever veiledningen som forvirrende og nedbrytende for egen arbeidsprosess:

Jeg tenker at den tilbakemeldingen jeg fikk sist, den skulle jeg fått før. Det hadde hjulpet meg ganske mye i det videre arbeidet. Nå føler jeg at jeg må begynne litt på nytt.

Egil følger opp den negative opplevelsen i det tredje fokusgruppeintervjuet og forklarer da hvordan dette virker inn på hans læringsopplevelse:

I stedet for en sånn trappetrinn, at du stadig øker kompetansen inn mot at prosessen skal avsluttes, så blir den satt tilbake igjen. Og du har et tidsperspektiv oppi dette her og er under press hele tiden på tid. Og det å bli satt tilbake på grunn av det kan bli frustrerende og irriterende.

Egils uttalelse om at det er frustrerende og irriterende når han ikke får riktig tilbakemelding på riktig tidspunkt, er verdt å legge merke til. Dette kan nemlig være et springende punkt for å holde oppe motivasjonen og læringstrykket hos studentene, som veilederne må ta på alvor.

Skrivingens bidrag til utvikling av lederkompetanse; faglig tyngde som gir trygghet

I fokusgruppeintervjuene undersøkte vi hvordan studentene oppfattet at skriving bidrar til yrkeskompetanse. Hovedinntrykket er at de forholder seg til sine egne opplevelser, litteratur og medstudenter gjennom skriving som de er pålagt i studiet. Vi finner at deltakerne gjennom å skrive opplever at de kobler sin egen praksis som ledere på en større kunnskapsbase, noe som gir følelse av sikkerhet og mestring. Skriving gir også perspektiv og bekreftelse på det studentene tenker og gjør som ledere. Det studentene uttrykker, bekrefter her hvordan ulike 
læringsprosesser forsterker hverandre gjennom skriving (Dale, 1983; Dysthe, Hertzberg \& Hoel, 2010).

Silje (2. fokusgruppe) sier det slik:

Silje: $\quad$ Nei altså. No er det lenge sidan eg har skrive sånne tekstar [Samtykkende lyder fra de andre i gruppa]. Så det er nytt for meg. Pluss at eg kjenner jo på at eg leser dei andre sine tekstar òg. Eller eg gjorde. No torer eg nesten ikkje det meir [latter]. Men eg ser jo at eg lærer av det òg. Og så tykkjer eg det er interessant. Eg leser meir teori òg. Artiklar som eg kjem over. Eg blir mykje meir bevisst denne forskinga og teoriforankringa inn mot det eg driv med.

Intervjuer: Men tenker du at det er verdifullt for det du driver med?

Silje: $\quad$ Ja, det er det.

Intervjuer: Hva er det som gjør det verdifullt?

Silje: $\quad$ Eg tykkjer det er spennande, på ein måte, i forhold til jobben min. Og så kjenner eg at eg brukar det meir inn når eg sit og snakkar med han som er rektor. Så brukar eg det. Eg berre seier ting som eg har lært da. Og det er litt sånn moro å vise at ein kan litt da, for å seie det. At ein lærer.

Silje hevder at hun har tilegnet seg nye perspektiver og arbeider mer aktivt med teori- og forskningsforankring av egen praksis. Hun peker på at arbeidet med tekstene har gjort henne mer bevisst på forskning og teori "inn mot det eg driv med”. Slik andre skolelederstudenter også har vært inne på (Lysø et al., 2012), forteller Silje hvordan hun oppfatter at skriving bidrar til koblinger av ulike typer kunnskap. Hun sier ikke noe om at det hun gjør i forhold til lærere og elever har endret seg, men synes det er moro at hun føler at hun kan og har lært, og bruker dette i samtaler med rektor. Slik viser hun også at hun opplever at arbeidet med skriving i rektorskolestudiet bidrar til økt mestringsopplevelse i jobben.

En økt mestringsopplevelse er noe Silje deler med de andre deltakerne. I intervjuene gir alle uttrykk for at de opplever å ha utviklet mer faglig tyngde gjennom å skrive. Deltakerne forklarer faglig tyngde som en sterkere teoretisk forankring for egen praksis, her illustrert ved Hanne (2. fokusgruppe):

Eg kjenner jo sjølv at eg får meir fagleg tyngde. Altså, eg veit meir om det å vere i leiinga no enn kva eg gjorde før eg byrja her, sant. Før eg måtte inn i disse teoriane og begynne å kika og lesa. Og det er jo ein form for fagleg tyngde det òg. Sjølv om det ikkje akkurat har med pedagogikk å gjere, eller med forvaltningssaker og sånn, så handlar det jo om korleis me skal driva skulen framover.

Ifølge Hanne handler faglig tyngde om at hun opplever en sterkere forankring for hva det vil si å være leder, og for utviklingsarbeidet i egen organisasjon. For Hanne har arbeidet med ledelsesteori gitt henne nye perspektiver på egen rolle. Hannes opplevelse av økt faglig tyngde speiler således kjerneelementet i Utdanningsdirektoratets ledelseskompetansebegrep, selve lederrollen, hvor den enkelte leder opplever seg trygg i rollen og utviser mot og kraft til å lede (Andreassen et al., 2010; Lillejord, 2011). I det sammensatte perspektivet på 
lederkompetanse som direktoratet fremmer, kan vi følgelig anta at Hanne, når hun opplever at hun har en større faglig tyngde, også vil oppleve mestring og kompetanse knyttet til ledelse av flere aspekter ved skolens virksomhet.

Opplevelsen av mestring og økt faglig tyngde knytter seg imidlertid ikke bare til at deltakerne har fått nye perspektiver. Mestringsfølelsen knytter seg også til at de opplever at arbeidet med integrering av teoretisk kunnskap i egen praksis har gitt bekreftelse på arbeidet de allerede gjør. Anita (2. fokusgruppe) beskriver det slik:

Jeg tenker også at ... Jeg overtok jo som rektor på den samme skolen som jeg jobbet. Og da hadde jeg jo formeninger om en del ting som jeg hadde lyst til å endre på. Og gjorde jo en del grep det første året. For det ene har jeg jo nå fått bekreftelse på at jeg hadde en del gode tanker da. Og det andre er jo at nå greier jeg i større grad å få disse tankene forankret ned i organisasjonen. For nå vet jeg hvordan jeg skal angripe det, for å få de andre med meg. Så det ... Jeg tror jeg har fått kontakt med golvet igjen. [Samtykkende lyder fra de andre i gruppa.]

For Anita handler opplevelsen av økt faglig tyngde om at hun opplever å ha fått bekreftelse på noen av de tankene og initiativene hun har lagt frem for personalet og satt i gang på egen skole det første året som rektor. Samtidig har arbeidet med skriving i studiet gitt henne mulighet til å reflektere over egne tanker og vurderinger og knytte disse sammen med mer generelle teorier rundt organisasjonsutvikling. Når Anita nå skal arbeide videre med utvikling, kan vi anta at hun kan gjøre dette med en sterkere tro på egne avgjørelser og kompetanse, samtidig som hun antyder at hun har utviklet mer kunnskap om hvordan hun skal "få de andre" med seg. Begge deler er sentrale egenskaper dersom skoleledere skal fremstå som legitime kunnskapsledere i egne skoler (Lillejord, 2011; Timperley, 2011; Robinson, 2010).

\section{Diskusjon}

I denne studien har vi undersøkt hvilke forutsetninger som må være til stede for at akademisk skriving skal bidra til utvikling av rektorskolestudenters lederkompetanse. Studien viser at deltakerne opplever akademisk skriving som vesentlig både for egen læring og i utvikling av egen kompetanse som leder. Dette kommer frem når deltakerne beskriver hvordan akademisk skriving gir dem en opplevelse av økt faglig tyngde. Her beskriver deltakerne at akademisk skriving først og fremst bidrar til utvikling i yrkeskompetanse gjennom en sterkere integrasjon mellom teoretisk og praktisk kunnskap. Gjennom arbeidet med skriving opplever deltakerne at teori og praksis ikke lenger opptrer som dikotomier, men som to sider av samme sak som står i en mer dynamisk relasjon til hverandre. Det er gjennom å arbeide med nettopp denne dynamikken mellom teoretiske perspektiver og egenerfarte utfordringer og problemstillinger at 
deltakerne opplever utvikling av det de kaller faglig tyngde. Slik faglig tyngde er avgjørende for deres legitimitet som ledere i egne skoler, hvor det “å kunne sitt fag er en forutsetning for enhver leder i et kunnskapssamfunn hvor kompetanse har blitt et sentralt kunnskapsbegrep" (Lillejord, 2011, s. 285). Dynamikken mellom teori og praksis i lederrollen har da ikke bare betydning for kvalitet og profesjonalitet i lederyrket (Elstad et al., 2014), men også for lederes legitimitet i egne organisasjoner.

Kunnskapsgrunnlaget for utøvelse av god skoleledelse er, som kompetansebegrepet illustrerer, svært sammensatt. For å opptre som kompetente skoleledere kreves det mer enn bare handling, eller som Davis med flere (2005) formulerer det: "It is not enough for principals to have a repertoire of behaviors; they must know how and when to use them, and they must be careful to monitor their effects on student learning” (Davis et al., 2005, s. 10). Dersom en skal utvikle skolelederes yrkeskompetanse og derigjennom deres profesjonalitet, må dette derfor innebære en utvikling av både skolelederes praksis og deres begrunnelser for praksis (Elstad et al., 2014). Vi står dermed overfor et kompetansebegrep som ikke tegner et bilde av teori og praksis som dikotomier, men som ulike sider ved lederkompetanse. Når deltakerne her gir uttrykk for at akademisk skriving bidrar til en økt faglig tyngde, kan det med andre ord ses som uttrykk for en helhetlig utvikling av lederkompetanse.

Her kommer denne helhetlige utviklingen av kompetanse til uttrykk ved at deltakerne beskriver at opplevelse av faglig utvikling også gir dem trygghet i egen rolle. I Siljes og Hannes beskrivelser av egen læring og utvikling av faglig tyngde fremkommer det også at de nå er mer bevisst på egen mestring og hva de kan. I arbeidet som skoleledere er det å vurdere andre høyt kompetente ansattes arbeid en sentral del av rollen. Slike vurderinger krever da ikke bare at en har faglig tyngde, men også at en har tillit til egne ferdigheter og kompetanse, og tillit til mandatet i egen rolle (Aas, 2011). Når det pekes på nettopp rolleforståelse som gir mot og kraft til å lede som et bærende element i skolelederkompetanse (Andreassen, Irgens \& Skaalvik, 2010; Møller \& Ottesen, 2011), kan deltakernes uttrykk for økt trygghet i lederrollen ses som et vesentlig bidrag i styrkingen av lederkompetanse (Langfeldt, 2008).

Samtidig er det viktig å påpeke at vår studie ikke kan forstås som en bekreftelse på at deltakernes opplevelse av kompetanseutvikling har betydning for måten de utøver sitt lederskap på. Vår studie avdekker først og fremst hvordan deltakerne opplever at skriving bidrar inn i deres læring og kompetanseutvikling. At deltakerne opplever at de lærer gjennom å skrive, og derigjennom føler seg tryggere i egen rolle, betyr ikke nødvendigvis at deres praksis endrer seg. Et eksempel er der hvor Anita forklarer at hun nå vet hvordan hun skal forankre sine tanker og ideer i organisasjonen. Det at hun har fått økt kunnskap om organisasjonsprosesser, kan styrke hennes mulighet for å fremme egne ideer i egen skole. Dette er imidlertid ikke en garanti for at hun realiserer denne kunn- 
skapen i praksis (Eide, 2015), eller at hennes ideer skal vinne frem (Aas, 2011; Møller, 2011).

Studien viser videre at deltakernes opplevelse av en sterkere integrasjon av teori og praksis i egen rolle kan problematiseres og nyanseres. Dette fremkommer i analysen av studenttekstene som avdekker deltakernes utfordringer med å bearbeide og omforme teori til analytiske begreper som kan tas i bruk når de prøver å forstå sin egen praksis. Her viser analysen vår at deltakernes teoribearbeidelse tar tid og først har form som reproduksjon, hvor teori og begreper siteres, mer enn at denne kunnskapen bearbeides og omformuleres til analytiske perspektiver som skolelederne kan ta i bruk for å forstå sin egen praksis (Dysthe, Hertzberg \& Hoel, 2010; Bazerman et al., 2013). Et sentralt funn i studien er at slik omarbeiding stiller krav til veiledningskvalitet. Et vesentlig veiledningsansvar i skolelederutdanningen blir da å støtte deltakerne i denne bearbeidelsen over tid, da dette er avgjørende for at teori og begreper skal ta form som kunnskap skolelederne kan ta aktivt i bruk i egen yrkesutøvelse (Bazerman, 2012). Her har studien avdekket at et slikt veiledningsansvar skaper didaktiske utfordringer i skolelederutdanningen når det gjelder veiledningskvalitet, med hensyn til å avveie mengde og presisjon i tilbakemeldinger, og når det gjelder å følge opp deltakernes teoribearbeidelse til rett tid, over tid og gjennom flere revisjoner av tekster.

\section{Konklusjon og forslag til videre arbeid}

Ut fra vår undersøkelse er det grunn til å anta at akademisk skriving utgjør et viktig bidrag i skoleledernes kunnskapstilegnelse og derigjennom deres kompetanseutvikling i rektorskolestudiet. Samtidig har studien avdekket vesentlige utfordringer for at akademisk skriving skal kunne fremstå som en viktig læringsstrategi for deltakerne, som deltakernes arbeid med å bearbeide og omforme teori til analytiske begreper som kan anvendes aktivt. Her peker undersøkelsen på både strukturelle og didaktiske virkemidler som kan styrke skoleledernes kunnskapstilegnelse. Både det eksisterende kunnskapsgrunnlaget (Dysthe, Hertzberg \& Hoel, 2010; Bazerman et al., 2013; Bazerman, 2012; Carter et al., 2007) og vår studie viser til at mulighet for å revidere tekster flere ganger kan styrke arbeidet. En didaktisk utfordring er da at mulighet for revisjon ikke i seg selv er tilstrekkelig for at teoribearbeidelsen skal utvikles videre fra en reproduserende form til aktiv kunnskap deltakerne kan bruke (Kellogg, 2008). Dette avhenger av veiledningskvalitet og av deltakernes evne til å nyttiggjøre seg tilbakemeldingene som gis. Denne studien peker således på flere spørsmål som bør undersøkes nærmere i fremtidige studier.

Et av dem er om utvikling av skolelederes yrkeskompetanse kommer til uttrykk i deres utøvelse av ledelse i egne skoler. Selv om vi gjennom denne undersøkelsen kan se en utvikling i studentenes måte å tenke på samt hva som må til 
for at studentene skal få ytterlige utbytte av skriving i studiet - og selv om studentene i intervjuene rapporterer om at de endrer seg som ledere - har vi ikke informasjon om hvordan dette i neste omgang faktisk virker inn på ledelsespraksis i skolen slik lærere og elever opplever det. Det har heller ikke vært denne studiens målsetning, men kan være interessant å følge opp i en ny studie. Spørsmålet om effekt av skolelederstudiet i skolene har vært forsøkt undersøkt i den nasjonale evalueringen av rektorskolen (Hybertsen et al., 2014), men man fant det vanskelig å finne svar på dette. Vi vet derfor fremdeles svært lite om hvordan ny kunnskap integreres i skoleledernes praksis og yrkesutøvelse underveis og etter endt utdanning. Vår undersøkelse åpner imidlertid for en antakelse om at skolelederne får økt sin kompetanse gjennom akademisk skriving.

Utgangspunktet som vi presenterte innledningsvis, var at kompetanse betyr å kunne handle, og at inspeksjon av kunnskapen som ligger til grunn for handlingene og utvikling av denne kunnskapen, er viktig for kompetanseutvikling. Denne undersøkelsen bekrefter at skriving er en effektiv strategi for å oppnå dette, og viser hvilke forutsetninger som må ligge til grunn for at skriving i denne sammenhengen skal ha ønsket effekt. Dette betyr at vi har noe kunnskap om akademisk skriving i skolelederutdanning som kan bygges videre på i praksis. Vi trenger imidlertid et bredere utvalg for å kunne fange opp flere styrker og svakheter ved skriving som læringsstrategi i denne konteksten, og vi trenger mer kunnskap om ulike kritiske faktorer for å få skriving til å fungere godt.

\section{Referanser}

Aas, M. (2011). Ledelse av profesjonelle læringsfellesskap. I J. Møller \& E. Ottesen (red.), Rektor som leder og sjef. Om styring, ledelse og kunnskapsutvikling i skolen (s. 186-201). Oslo: Universitetsforlaget,.

Andreassen, R. A., Irgens, E. J. \& Skaalvik, E.M. (2010). Kompetent skoleledelse.

Trondheim: Tapir akademisk forlag.

Bakthin, M. M. (1990). The Dialogic Imagination: four essays. Austin, Texas: University of Texas Press.

Bazerman, C. (2012). Writing with concepts: Communal, Internalized and Externalized.

Mind, Culture, and Activity, 19(3), 259-272.

Bazerman, C., Simon, K., Ewing, P. \& Pieng, P. (2013). Domain Specific Cognitive

Development through Writing Tasks in a Teacher Education Program. Pragmatics \&

Cognition. Writing and the Mind, 21(3), 530-551. doi:

https://doi.org/10.1075/pc.21.3.07baz

Bazerman, C. (1988). Shaping Written Knowledge. Madison: University of Wisconsin Press.

Bazerman, C. (1981). What written knowledge does: Three examples of academic discourse, Philosophy of the Social Sciences, 11(3), 361-388.

Bereiter, C. \& Scardamalia, M. (1987). The psychology of written composition. Hillsdale, NJ: Erlbaum.

Black, P. \& William, D. (2009). Developing the theory of formative assessment. Educational Assessment, Evaluation and Accountability, 21(5), 5-31. 
Çavdar, G. \& Doe, S. (2012). Learning through writing: Teaching Critical Thinking Skills in Writing Assignments. Political Science and Politics,45(2), 298-306.

Caroll, L. (2002). Rehearsing new roles: How college students develop as writers. Carbondale: Southern Illinois University Press.

Carter, M., Ferzli, M. \& Wiebe, E. N. (2007). Writing to learn by learning to write in the disciplines. Journal of business and Technical Communication, 21(3), 278-302.

Dale, G. L. (1983). Ler oss å lese. Lese- og skrivevansker hos unge og voksne. Oslo: Universitetsforlaget.

Davis, S., Darling-Hammond, L., LaPointe, M. \& Meyerson, D. (2005). School Leadership Study. Developing Successful Principals. Stanford: Stanford educational Leadership Institute.

Day, C., Leithwood, K. \& Sammons, P. (2008). What have we learned, what we need to know more about. School Leadership \& Management, 28(1), 83-96.

Day, C., Sammons, P., Hopkins, D., Leithwood, K. \& Kington, A. (2008). Research into the impact of school leadership on pupil outcomes: policy and research contexts. School Leadership and Management, 28(1), 5-25.

Dysthe, O. (2011). "What is the Purpose of Feedback when Revision is Not Expected?” A Case Study of Feedback Quality and Study Design in a First Year Master's Programme. Journal of Academic Writing, 1(2), 135-142.

Dysthe, O., Herzberg, F. \& Hoel, T. L. (2010). Skrive for å lære. Oslo: Abstrakt forlag AS.

Dysthe, O. (1999) (red.). Ulike perspektiv på læring og læeringsforskning. Oslo: Cappelen Akademisk Forlag AS.

Eide, H. M. K. (2015). Narrating the relationship between leadership and learning outcomes: A study of public narratives in the Norwegian educational sector. PhD-avhandling, Universitetet i Bergen.

Elstad, E., Helstad, K. \& Mausethagen, S. (2014). Profesjonsutvikling i skolen. I E. Elstad \& K. Helstad (red.). Profesjonsutvikling i skolen (s. 17-38). Oslo: Universitetsforlaget.

Flower, L. (1990). Reading to write: Exploring the cognitive and social process. New York: Oxford University Press.

Freeman, D. (2002). The hidden side of the work: Teacher knowledge and learning to teach. Language Teaching, 35(1), 1-13. doi: http://dx.doi.org/10.1017/S0261444801001720

Gamlem, S. M. \& Smith, K. (2013). Student perceptions of classroom feedback. Assessment in Education: Principles, Policy \& Practice, 20(2), 150-169.

Goodson, I. (1997). The Life and Work of Teachers. I B. J. Biddle, T. L. Good \& I. F. Goodson (red.), International Handbook of Teahcers and Teaching (s. 135-152). Dordrecht/Boston/London: Kluwer Academic Publishers.

Halkier, B. (2010). Fokusgrupper. Oslo: Gyldendal akademisk.

Hatch, J. A. (2002). Doing qualitative research in education settings. New York: State University of New York Press.

Hybertsen, I. D., Stensaker, B., Federici, R. A., Olsen, M. S., Solem, A. \& Aamodt, P. O. (2014). Ledet til endring. Nasjonal rektorutdanning i grunn- og videregående skole; endringer på skolene, måloppnåelse og anbefalinger. Sluttrapport fra Evalueringen av den nasjonale rektorutdanningen. NIFU, NTNU Samfunnsforskning AS.

Kellogg, R. T. (2008). Training writing skills: A cognitive developmental perspective. Journal of writing research, 1(1), 1-26.

Kvale, S. \& Brinkmann, S. (2009). Det kvalitative forskningsintervju. Oslo: Gyldendal akademisk.

Langfeldt, G. (2008). Ansvar og kvalitet. Strategier for styring i skolen. Kristiansand: Cappelen Akademisk Forlag. 
Leithwood, K. \& Day, C. (2008). The impact of school leadership on pupil outcomes. School Leadership \& Management, 28(1), 1-4.

Leithwood, K., Harris, A. \& Hopkins, D. (2008). Seven strong claims about school leadership. School Leadership \& Management, 28(1), 27-42.

Lillejord, S. (2011). Kunsten å være rektor. I J. Møller \& E. Ottesen (red.), Rektor som leder og sjef. Om styring, ledelse og kunnskapsutvikling i skolen (s. 284-301). Oslo: Universitetsforlaget.

Lysø, I. H., Stensaker, B., Røthe, R., Federici, R. A., Olsen, M. S. \& Solem, A. (2012). Ledet til lederutvikling. Nasjonal rektorutdanning i grunn- og videregående skole; forskjeller og likheter mellom de seks programtilbudene. Delrapport 2 fra Evaluering av den nasjonale rektorutdanningen. NIFU, NTNU Samfunnsforskning AS.

Malterud, K. (2003). Kvalitative metoder i medisinsk forskning. Oslo. Universitetsforlaget.

Mintzberg, H. (2010). Managing on three planes. Leader to Leader, 2010(57), 29-33.

Møller, J. (2011). Rektorers profesjonsforståelse - faglig autonomi og administrativ underordning. I J. Møller \& E. Ottesen (red.), Rektor som leder og sjef. Om styring, ledelse og kunnskapsutvikling i skolen (s. 27-50). Oslo: Universitetsforlaget.

Møller, J. \& Ottesen, E. (2011). Styring, ledelse og kunnskapsutvikling i skolen. I J. Møller \& E. Ottesen (red.), Rektor som leder og sjef. Om styring, ledelse og kunnskapsutvikling i skolen (s. 15-26). Oslo: Universitetsforlaget.

Robinson, V. M. J. (2010). From Instructional Leadership to Leadership Capabilities: Empirical Findings and Methodological Challenges, Leadership and Policy in Schools, 9(1), 1-26.

Rommetveit, R. (1974). On Message Structure. London/New York: Wiley.

Silverman, D. (2011). Interpreting Qulitative Data. Methods for Analyzing Talk, Text and Interaction. London: Thousand Oaks; New Delhi: Sage Publication Ltd.

Timperley, H. (2011). Knowledge and the leadership of learning, Leadership and policy in schools, 10(4), 395-411.

Tolo, A. (2011). Hvordan blir larerkompetanse konstruert? En kvalitativ studie av PPUstudenters kunnskapsutvikling. PhD-avhandling, Universitetet i Bergen. 